\title{
A Conversation with John Dewey and Carter G. Woodson concerning Experience and Education, Education and Social Justice, and Culturally Responsive Teaching
}

\author{
Dr. Magnus O. Bassey \\ Professor \\ Department of Secondary Education and Youth Services \\ Queens College \\ The City University of New York \\ 65-30 Kissena Blvd \\ Flushing, New York, 11367, USA
}

\begin{abstract}
In most of his major works, John Dewey makes a connection between experience and education, education and social justice. In this paper, I argue that the relationship between experience and education, education and social justice is most profoundly illustrated in the work of Carter G. Woodson.
\end{abstract}

\section{What is Education and what is Educative Experience?}

Dewey (1916 \&1938) argued that in learning, there is some interplay between experience and education. In, Experience and Education, he described succinctly this connection. He argued that the more salient factors contributing to a student's learning is the interaction between the student's experience and his or her environment. According to Dewey (1916), education is, "that reconstruction or reorganization of experience which adds to the meaning of experience, and which increases ability to direct the course of subsequent experience" (pp. 82-83). However, "some experiences are mis-educative" (Dewey, 1938/1998, p.13). A mis-educative experience "has the effect of arresting or distorting the growth of further experience" (p.13). Martusewicz (2004, p.4) frames the argument that "transformations [which] reproduce conditions, e.g., ideologies, attitudes, relationships or practices, or social and economic structures that may be harmful to others," are mis-educative. However, Dewey (1938/1998) defined education as growth and educative experience as continuity through renewal and postulates that "Growth, or growing as developing, not only physically but intellectually and morally, is one exemplification of the principle of continuity" (p. 28). In his conceptual framework, Dewey explained that a man who grows in efficiency as a gangster or as a burglar or as a corrupt politician would not qualify from the "standpoint of growth as education and education as growth" (p.29).Dewey(1938/1998) saw educative experience as a moving force whose "value can be judged only on the ground of what it moves toward and into" (p. 31). Responding to Dewey’s (1938) work, Maxine Greene (1998) commented,

For Dewey, the notion of experience referred to all human transactions, all encounters with the physical and human world. If education was to mean anything at all, it had to involve a heightened reflectiveness with respect to lived experience, a more conscious thoughtful way of being in the world. Without such an approach to experience, it was highly unlikely that a pursuit of knowledge could begin. (119-120)

Carter G. Woodson (1875-1950), a man who lived at about the same time and during the same era as John Dewey had earlier offered a definition of education in his book, The Mis-Education of the Negro (1933/1993). In the book he pointed out that Blacks were not given the right type of education because their education was not drawn from their own experiences. According to Woodson, the type of education given to Blacks subjected them to the will of others and was not "determined by the make-up of the [people]themselves and by what [their] environment requires of [them]" (p. $\mathrm{x})$. Woodson argued that the type of education given to Black children was mis-educative because it "created a split in the personality of blacks typified by dual identities resulting in a profound identity crises which has made educated African Americans" (Asante, 1990, p. 167), to "decry any such thing as race consciousness"(Woodson, 1933/1993, p.7). He stated, "The chief difficulty with the education of the Negro is that it has been largely imitation resulting in the enslavement of his mind" (p.134). He went on to say that Blacks were never educated but were only informed about the world and about things around them (p.144), because education for Blacks was determined from without. As a corrective to mis-education, Woodson suggested that education for Black children should be determined by the makeup of the people themselves and should be carried out according to the circumstances which their environment requires of them. This is because education which is dictated by one's environment allows the individual to think for him or herself. Similarly, John Dewey saw educative experience as growth that leads to further growth. 
According to him, "Any experience is mis-educative that has the effect of arresting or distorting the growth of further experience"(1938/1998 p. 13).He defined mis-educative experiences to include callousness, insensitivity and lack of responsiveness (p.13).

\section{The Importance of Experience in Education}

As I have noted in the previous paragraphs, Dewey (1916\&1938) argued that there is an organic connection between experience and education and in Experience and Education in particular, he talks about students "delving into their roots in the past" (p. 93).To illustrate this point, he stated:

Just as the individual has to draw in memory upon his own past to understand the conditions in which he individually finds himself, so the issues and problems of present social life are in such intimate and direct connection with the past that students cannot be prepared to understand either these problems or the best way of dealing with them without delving into their roots in the past. In other words, the sound principle that the objectives of learning are in the future and its immediate materials are in present experience can be carried into effect only in the degree that present experience is stretched, as it were, backward. It can expand into the future only as it is also enlarged to take in the past.(p.93)

On his own part, Woodson was consciously deliberate in arguing that Black children were not given the right type of education because their education lacked the interplay between the students and their experiences and because their education subjected them to the will of others. In other words, education given to Black children was not determined by what their environment requires of them(Woodson, 1993, X).

\section{Education, Political Consciousness and Social Justice}

According to Matthew C. Altman, citizenship education should "prepare students to participate in public dialogue about questions of justice and morality" (cited in Waghid 2005, p.323). According to Heybach, (2009), "Dewey called on teachers and schools to become agents of individual transformation"(p. 240). It is instructive to point out that at the time Dewey wrote some of his major works, both the American public, educators and education philosophers "wanted schools to assimilate students into American life, combining the basics of English and arithmetic with emphasis on patriotism, hard work, fair play, and honesty"(Graham, 2005,ff). With the wave of new immigrants into the United States in the twentieth century, John Dewey called for schools to emphasize socialization, development of patriotism and full citizenship. But as Graham (2005) has pointed out, "John Dewey and his high-toned colleagues had much more subtle notions of patriotism in mind, ones that recognized the obligations of both the citizen to the state and of the state to the citizen, including the citizens' responsibility to serve the state through their enlightened criticism of it" (p.24).

Dewey (1916/1966) believed that education is the "construction or reconstruction of experience," because "every experience both takes up something from those which have gone before and modifies in some way the quality of those which come after" (Dewey, 1938/1998, p. 27).

Both Dewey and Woodson believed in education for social justice. They wanted schools to uncover and change permanently institutions that commemorate systemic oppression. In an article entitled, "The School as a Means of Developing A Social Consciousness and Social Ideals in Children," Dewey (1923) called on schools to do "really fundamental work of improving the health and culture of the community, and in spreading liberty and justice and happiness throughout ..." (p. 517).Similarly, Woodson (1933/1993) called on schools to expose institutions and organizations which perpetuate systemic oppression and called on educated people "to revolutionize the social order for the good of the community" (p. 145). He went on to say that the "educational system of a country is worthless unless it accomplishes this task," and concluded, "Men of scholarship and consequently of prophetic insight must show us the right way and lead us into the light which shines brighter and brighter" (p.145).

\section{Culturally Responsive Teaching}

Woodson believed that academic attainment should include student learning, cultural proficiency and political consciousness. He argued that educators should not only use students' prior experiences and frames of reference to make learning more relevant, but they should develop in their students sociopolitical consciousness that would enable them to critique society not as it is but as it should be (Woodson, 1933/1993, pp.142-146; see also Ladson-Billings, 1995, 2009; Delpit, 1995; Gay, 2010).Lisa Delpit (1995), one of the leading proponents of culturally responsive teaching makes a similar point by suggesting,

that [students] must be allowed the resource of the teacher's expert knowledge, while being helped to acknowledge their own "expertness" as well; and that even while students are assisted in learning the culture of power, they must also be helped to learn about the arbitrariness of those codes and about the power relationships they represent. (p. 45) 
In as much as Woodson (1933/1993) believed that teachers should cultivate a nurturing and supportive learning environment for their students, he wanted schools to be infused with very robust cultural sensitivities with emphasis on the centrality of experience in what scholars today call culturally responsive teaching. Geneva Gay (2010, p. 31) tells us that culturally responsive teaching "is using the cultural knowledge, prior experiences, frames of reference, and performance styles of ethnically diverse students to make learning encounters more relevant to and effective for [students]." Another leading scholar in this field, Gloria Ladson-Billings (2009) informs us that culturally responsive teaching "empowers students intellectually, socially, emotionally, and politically [because it uses]cultural referents to impart knowledge, skills, and attitudes" (p. 20). In an earlier article Ladson-Billings noted that culturally responsive teaching is:

a pedagogy of opposition not unlike critical pedagogy but specifically committed to collective, not merely individual, empowerment. Culturally relevant pedagogy rests on three criteria or propositions: (a) Students must experience academic success; (b) students must develop and/or maintain cultural competence; and (c) students must develop a critical consciousness through which they challenge the status quo of the current social order. (cited in Howard and Rodriguez-Scheel, 2017, p. 3)

Indeed, studies by Gehlbach (2014); Johnson, Nyamekye, Chazan and Rosenthal(2013); Aguirre and Zavala (2013); Gay (2010); Camangian (2010); Cammarota and Romero (2009); Ladson-Billings (1992, 1995, 2009); Ensign (2003); Civil and Khan (2001); Delpit (1995); Lipman (1995); Shujaa (1995) and Tate (1995), all show that students in classes where teachers use culturally responsive teaching make tremendous academic progress. This is because these teachers are enthusiastic about their work; they show tremendous respect for parents and they understand that Black students operate in many worlds: their home environment, the world of the school, and the global community. Scholarship emanating from these studies underscores the fact that teachers who use culturally responsive method of teaching are successful because they infuse their classrooms with robust cultural sensitivities as Woodson suggested. These teachers build bridges between the home and the school community. They use various instructional strategies and teaching styles to meet the needs of individual students, and use a variety of multicultural resources, information and materials to apply across the various subject areas. (Bassey, 2010, 2015, 2016,2017; Howard and Rodriguez-Scheel, 2017). Further examination of these studies shows that the teachers who use culturally responsive teaching in their classrooms have very few discipline problems in their classes and they have very high attendance rates. As a result, their students score at the highest percentile on standardized tests (Gehlbach, 2014; Johnson, Nyamekye, Chazan and Rosenthal, 2013; Gay, 2010; Ladson-Billings, 2009; Delpit, 1995; Lipman, 1995; Shujaa, 1995; Tate, 1995). The essence of culturally responsive teaching according to Howard and Rodriquez-Scheel (2017), is that itencourages practitioners, "to care authentically, to tap into prior knowledge in a sustained and non-judgmental manner, to respect and learn youth literacies, and to see the clear connections between how culturally diverse students navigate and understand the world, and how that knowledge can serve as an invaluable bridge to mastering academic content and having positive school experiences" (P. 6; see also Gay and Kirkland, 2003; Athanases, Wahleithner and Bennett, 2012; Hammond, 2015). Apart from its academic component, culturally responsive teaching is informed by the principles of freedom, equality and social justice. This is to say, in culturally responsive classrooms, students are not only required to perform well academically, they are challenged to uncover the causes of injustice. In the same compelling manner, the overriding characteristic of a good education in Woodson's scheme was to help students ask not only existential questions but compel them to challenge political, social and economic inequalities in society. Woodson informs us that the best way of approaching an educational enterprise is by producing knowledgeable and engaged citizens who would be able to confront democratic incongruities, contradictions and imperfections such as racism (Woodson, 1933/1993, pp. 145146).Asking existential questions and challenging injustices were important aspects of education for Woodson because, "those who have not learned to do for themselves and have to depend solely on others never obtain any more rights or privileges in the end than they had in the beginning" (Woodson, 1933/1993, pp. 186-187).

\section{Conclusion}

In this article, I have highlighted the contributions of two very important American educational theorists, John Dewey and Carter G. Woodson and concluded that, in practical terms, their enormous contributions to educational thought qualify themas precursors of culturally responsive teaching because culturally responsive teaching has found solid theoretical bases in their works. Although the nexus connecting the works of these two educational theorists to culturally responsive teaching is so very apparent when examined with analytical eyes, this nexus has never been clearly attributed. 


\section{References}

Aguirre J. M.,\& Zavala, M. (2013). Making culturally responsive mathematics teaching explicit: A lesson analysis tool. Pedagogies: An International Journal, 8(2), 163-190.

Asante, M. K. (1990).Kemet, Afrocentricity and Knowledge. Trenton, NJ: Africa World Press Inc.

Athanases, S. Z., Wahleithner, J. M., \& Bennett, L. H. (2012). Learning to attend to culturally and linguistically diverse learners through teacher inquiry in teacher education. Teachers College Record, 114(7), 1-50 http://www.tcrecord.org ID Number 16470, Date Accessed 3/14/2014.

Bassey, M. O. (2010). Education for civic citizenship and social justice: A critical social foundations approach. Education as Change, 14(2), 247-257.

Bassey, M. O. (2015). The centrality of experience in Carter G. Woodson's, The mis-education of theNegro. Journal of Philosophy \& History of Education, 65(1), 123-135.

Bassey, M. O. (2016). Culturally responsive teaching: Implications for educational justice. Education Sciences, 6 (4), $1-6$.

Bassey, M. O. (2017). Just what Carter G. Woodson ordered: Culturally responsive education and teaching. Journal of Education and Human Development, 6(4), 1-6.

Camangian, P. (2010). Starting withself: Teaching autoethnography to foster critically caring literacies. Research in the Teaching of English, 45(2), 179-204.

Cammarota, J.,\& Romero A. F. (2009). The social justice education project: A critically compassionate intellectualism for Chicana/o students. In W. Ayers, T. Quinn, \& D. Stovall (Eds.), Handbook of social justice in education (pp. 465-476). New York, NY: Routledge.

Civil, M.,\& Khan, L. H. (2001). Mathematics instruction developed from a garden theme. Teaching Children Mathematics, 7(7), 400-405.

Delpit, L. (1995). Other people's children: Cultural conflict in the classroom. New York: The New Press.

Dewey, J. (1916/1966). Democracy and education. New York: The Free Press.

Dewey, J. (1923). The school as a means of developing a social consciousness and social ideals in children. Journal of Social Forces, 1(5), 513-517.

Dewey, J. (1938/1998). Experience and education. West Lafayette, Indiana: Kappa Delta Pi.

Ensign, J. (2003). Including culturally relevant math in an urban school. Educational Studies, 34(4), 414-423.

Gay, G. (2010). Culturally responsive teaching: Theory, research, and practice ( $2^{\text {nd }}$ edition). New York, NY: Teachers College Press.

Gay, G. \& Kirkland, K. (2003). Developing cultural critical consciousness and self-reflection in preservice teacher education. Theory into Practice 42(3) 181-187.

Gehlbach, H. (2014, 19 November). Creating birds of similar feathers: Leveraging similarity to improve teacherstudent relationships and academic achievement. SEYS Educational Psychology Lecture Series, Department of Secondary Education and Youth Services, Queens College, The City University of New York.

Graham, P. A. (2005). Schooling America: How the public schools meet the nation's changing needs. New York: Oxford University Press.

Greene, M. (1998). Experience and education: Contexts and consequences. In John Dewey, Experience and education, The $60^{\text {th }}$ Anniversary Edition (pp. 118-130). West Lafayette, IN: Kappa Delta Pi. First Published in 1938.

Hammond, Z. (2015). Culturallyresponsive teaching \& the brain. Thousand Oaks, CA: Corwin.

Heybach, J. (2009). Rescuing social justice in education: A critique of the NCATE controversy. Ohio Valley Philosophy of Education Society, 40, 234-245.

Howard, T. C.,\& Rodriguez-Scheel, A. (2017). Culturally relevant pedagogy 20 years later: Progress or pontificating? What have we learned, and where do we go? Teachers College Record, 119(1), 1-32. https://www.tcrecord.org ID Number: 21718, Date Accessed: 5/25/2019.

Johnson, W., Nyamekye, F., Chazan, D., \& Rosenthal, B. (2013). Teaching with speeches: A Black teacher who uses the mathematics classroom to prepare students for life. Teachers College Record, 115 (2), 1-26. http://www.tcrecord.org ID Number: 16829, Date Accessed: 9/22/2014.

Ladson-Billings, G. (1992). Reading between the lines and beyond the pages: A culturally relevant approach to literacy teaching, Theory into Practice 31(4), 312-320.

Ladson-Billings, G. (1995). But that's just good teaching! The case for culturally relevant pedagogy. Theory into Practice, 34(3), 159-165.

Ladson-Billings, G. (2009). The dreamkeepers: Successful teachers of African American children ( $2^{\text {nd }}$ edition.). San Francisco, CA: Jossey-Bass. 
Lipman, P. (1995). "Bringing out the best in them": The contribution of culturally relevant teachers to educational reform. Theory into Practice, 34(3), 202-208.

Maiga, H. O. (1995). Bridging classroom, curriculum, and community: The Gao school museum. Theory into Practice, 34(3), 209-215.

Martusewicz, R. A. (2004). Editor's corner. Educational Studies, 35(1), 1-6.

Shujaa, M. J. (1995). Cultural self meets cultural other in the African American experience: Teachers' responses to a curriculum content reform. Theory into Practice, 34(3), 194-201.

Tate, W. F. (1995). Returning to the root: A culturally relevant approach to mathematics pedagogy. Theory into Practice, 34(3), 166-173.

Waghid, Y. (2005). Action as an educational virtue: Toward a different understanding of democratic citizenship education. Educational Theory, 55(3), 323-342.

Woodson, C. G. (1933/1993). The mis-education of the Negro. Trenton, NJ: Africa World Press, Inc. 